\title{
Civilisations
}

Revue internationale d'anthropologie et de sciences

humaines

$41 \mid 1993$

Mélanges Pierre Salmon II

\section{Changing determinants of african mineworker mortality: Witwatersrand and the Copperbelt, 1911-1940}

Bruce Fetter

\section{OpenEdition}

\section{Journals}

\section{Electronic version}

URL: http://journals.openedition.org/civilisations/1721

DOI: 10.4000/civilisations. 1721

ISSN: 2032-0442

\section{Publisher}

Institut de sociologie de l'Université Libre de Bruxelles

\section{Printed version}

Date of publication: 1 September 1993

Number of pages: $347-359$

ISBN: 2-87263-094-5

ISSN: 0009-8140

\section{Electronic reference}

Bruce Fetter, «Changing determinants of african mineworker mortality: Witwatersrand and the Copperbelt, 1911-1940», Civilisations [Online], 41 | 1993, Online since 30 July 2009, connection on 19 April 2019. URL : http://journals.openedition.org/civilisations/1721 ; DOI : 10.4000/civilisations.1721

This text was automatically generated on 19 April 2019

(c) Tous droits réservés 


\title{
Changing determinants of african mineworker mortality: Witwatersrand and the Copperbelt, 1911-1940
}

\author{
Bruce Fetter
}

1 Comparison of the changing causes of death in two of Industrial Africa's largest mining companies can indicate both characteristics of the protean work forces and differences in company medical policies. Both the Corner House Group on the Witwatersrand and the Union Minière in what was then Katanga were reticent in reporting both mortality levels among their African workers and on causes of death. This essay will explore statistical data provided in some relatively obscure publications which throw additional light on the health consequences of early stages of the industrialization process in Africa.

2 In both South Africa and what is today Zaïre, large scale mining began in the absence of a labor market. European-managed mining companies therefore had the double task of finding workers and persuading them to stay on the job. In the early years managements depended for labor on constraint applied either directly by labor touts or indirectly by colonial governments which imposed taxes on African populations payable only in European money. Even then, certain potential sources were excluded because of political considerations. In South Africa, objections by European miners and politicians resulted in the elimination of Chinese workers after 1907, and those of British officials in Central Africa led to bans on the recruitment of "tropical" Africans between 1912 and $1933^{1}$. Similarly, Belgian officials beginning in 1926 restricted recruitment for the copper mines to the Belgian Congo and Ruanda-Urundi² .

3 Once workers were found, managers had to assure working and living conditions conductive to production. Africans responded eagerly to monetary incentives, but they also had to be kept in good health in order to maximize their productivity. The development of the mineral industry in Africa after 1900 depended on recent advances in tropical hygiene made in other parts of the world. New institutes of tropical medicine in 
London, Liverpool, Brussels (later Antwerp), and Hamburg analyzed tropical microorganisms and the vectors which transmitted them. Military physicians and engineers applied many of these advances to tropical conditions for both warfare and public works. The best-known of these tropical hygienists was Colonel (later Surgeon-General) William C. Gorgas who supervised sanitary activities at the construction of the Panama Canal. Under daunting conditions which had led an earlier French group to abandon construction, Gorgas established a set of procedures which sharply reduced mortality from both tropical and global diseases which had decimated workers on the earlier project ${ }^{3}$.

4 Late in 1913 the Chamber of Mines invited Gorgas to South Africa as a consultant to make recommendations for improving conditions for its work force. Upon his return to the United States, Gorgas produced an elaborate report which proved unacceptable to both the South African government and to the top management of the mining industry ${ }^{4}$. The most important sticking points were his recommendations to allow African miners to live at the mine sites with their wives and children and to centralize the provision of hospital care among mines of different ownership ${ }^{5}$. Despite the rejection of these suggestions, the management of the largest mining consortium, the Corner House Group, asked Gorgas to recommend a director for their health services. He submitted the name of a protégé from his Panama days, Dr. Alexander Orenstein, who moved to South Africa where he spent a long career.

5 Through Orenstein, Gorgas's influence also reached the Katanga mines. Shortly after the First World War, Dr. A. Boigelot of the colonial health service visited South Africa to see how South African companies, led by the Corner House Group, were reducing mortality rates on the mines ${ }^{6}$. His account of his visit led the Union Minière to invite Orenstein to Katanga as a consultant. Although Orenstein's mandate was limited to anti-malarial measures, he also made suggestions for changes in African housing facilities and undoubtedly to spoke to his Belgian hosts about Gorgas's original recommendations for South $\mathrm{Africa}^{7}$. Union Minière managers, unhindered by settler politicians or an effective white trade union movement, eventually (1926) adopted his stabilization of labor policy, which called for the implantation of workers with their families ${ }^{8}$.

6 The managements of the Corner House Group and the Union Minière shared many common concerns while operating in rather different political environments. I have earlier argued that these political differences were a major determinant of differences in worker health'. Let us now look at statistics relating to the mortality of the respective worker populations to see whether that argument can be sustained.

7 Neither company was eager to publicize statistics relating to the health of its workers. Although internal documents discussed the matter frankly, managers felt they might be compromised by the high levels of mortality. The Union Minière, however, was subject to outside political pressures. During the mid-twenties, a number of colonial agencies including the government felt they were in competition for a limited number of African workers. As a result, mortality statistics for various employers were reported in annual government reports to the Belgian Parliament. By the early thirties, Union Minière managers were justly proud of their achievements and lost their reluctance to publicize conditions in the camps. From that point onward, mine physicians such as Robert van Nitsen and representatives of the company's Native Labor Service, led by Léopold Mottoulle, eagerly presented the latest statistics ${ }^{10}$. It was not until the Second World War, however, that cause of death statistics for the early years were analyzed by Dr. Robert 
Mouchet in a paper given during the German occupation to the Royal Academy of Colonial Sciences ${ }^{11}$.

Table 1: Crude death rates at corner house and the union miniere

\begin{tabular}{|c|c|c|}
\hline YEAR & CORNER HOUSE & UNION MINIERE \\
\hline 1911 & 35 & \\
\hline 1912 & 25 & \\
\hline 1913 & 18 & \\
\hline 1914 & 19 & 65 \\
\hline 1915 & 15 & 52 \\
\hline 1916 & 13 & 92 \\
\hline 1917 & 20 & 106 \\
\hline 1918 & 17 & 202 \\
\hline 1919 & 18 & 51 \\
\hline 1920 & 14 & 33 \\
\hline 1921 & 13 & 27 \\
\hline 1922 & 15 & 31 \\
\hline 1923 & 14 & 33 \\
\hline 1924 & 13 & 30 \\
\hline 1925 & 12 & 50 \\
\hline 1926 & 13 & 53 \\
\hline 1927 & 16 & 45 \\
\hline 1928 & 16 & 33 \\
\hline 1929 & 13 & 23 \\
\hline 1930 & 14 & 18 \\
\hline 1931 & 13 & 12 \\
\hline 1932 & 11 & 8 \\
\hline 1933 & 11 & 7 \\
\hline 1934 & & 6 \\
\hline 1935 & & 6 \\
\hline 1936 & & 8 \\
\hline 1937 & & 9 \\
\hline 1938 & & 8 \\
\hline 1939 & & 5 \\
\hline 1940 & 6 & 5 \\
\hline
\end{tabular}

Sources: Corner House: Gorgas Papers, W.S. Hoole Special Collection, University of Alabama Library Report on Nyasaland Natives in the Union of South Africa and in Southern Rhodesia (Zomba, 1937); Rand Mines Annual Report 1964. Union Minière - Service Médical, Rapports annuels, 1930.

Corner House managers were even more tight-lipped than those of the Union Minière. Some statistics were reported at the time of Gorgas's mission just before the First World War, but for the next twenty years, little seems to have been available in periodicals such as the South African Medical Journal and the Proceedings of the (Transvaal) Mine Medical Officers' Association. Orenstein broke the silence in a report to the Third Empire Mining and Metallurgical Congress in 1930, divulging mortality levels and changing causes of death among Corner House Group employees for the years 1911 and 1928 without providing statistics for the years in between ${ }^{12}$. Those appeared only in the mid-thirties when the company was trying to convince British administrators in what is now Malawi to allow the resumption of recruitment for the gold mines. In 1937, the Corner House Group revealed annual figures for Crude Death Rates, pneumonia, tuberculosis, and accidents in the form of a semi-logarithmic graph presented to John C. Abraham, the Senior Provincial Commissioner for Nyasaland ${ }^{13}$. This format exaggerated small recent changes in mortality level at the expense of older, larger ones.

9 Table 1 shows the Crude Death Rates for the camps of the two companies between 1911 and 1940. Mining operations were begun on the Witwatersrand in 1886, some 25 years before the beginning of copper mining in Katanga, and, in that time, South African managers made certain investments in the infrastructure of housing and health care which reduced mortality. In the early years of the twentieth century, Crude Death Rates 
there were lower than in Katanga. Indeed, copper company CDRs did not definitively cross the 30 per thousand threshold until 1929. As far as the Corner House Group was concerned, mortality rates fell as a combined result of personnel selection and improvements in medical facilities and in personnel selection and improvements in medical facilities and in public health. The first major decline shown in Table 1 from about 30 to below 20 per thousand took place between 1911 and 1913 as a result of a ban on the recruitment of Africans from north of the Tropic of Capricorn, who experienced far higher mortality levels than Africans from the temperate zone. For the rest of the decade, despite a number of improvements brought by Orenstein, mortality levels remained in the high teens. Indeed, before 1933, Corner House CDRs never fell as low as ten per thousand, a rate achieved by Gorgas on the Panama Canal construction in $1912^{14}$. In the absence of age specific mortality statistics, part of the higher CDRs could result from an older work force on the mines, but the contrast is nonetheless striking.

As far as the Union Minière is concerned, CDRs reached a disastrous peak of 202 per thousand in the Spanish Influenza year of 1918 and were as high as 53 in 1926. From that point onward, however, rates plummeted, crossing those of the Corner House Group in 1931. These latter improvements seem the direct result of the stabilization policies which included not only lodging workers' nuclear families on the mine sites but also substantial expenditures on housing, food, and medical care. Let us examine cause of death statistics to see if we can identify which of the policies is most closely associated with mortality reduction.

Table 2: cause of death by illness corner house

\begin{tabular}{|c|c|c|c|c|}
\hline Disease & $\frac{1911}{\text { Death Rate }}$ & $\begin{array}{l}\text { Percentage } \\
\text { of Deaths }\end{array}$ & $\frac{1928}{\text { Death Rate }}$ & $\begin{array}{l}\text { Percentage } \\
\text { of Deaths }\end{array}$ \\
\hline Pneumonia & 12.3 & 35.0 & 5.5 & 34.4 \\
\hline Scurvy & 0.7 & 2.0 & 0.1 & 0.6 \\
\hline $\begin{array}{l}\text { Typhoid- } \\
\text { Paratyphoid }\end{array}$ & 2.8 & 8.0 & 1.5 & 9.4 \\
\hline Other Diseases & 14.0 & 39.9 & 5.6 & 35.0 \\
\hline Accidents & 5.3 & 15.1 & 3.3 & 20.6 \\
\hline Total & 35.1 & 100.0 & 16.0 & 100.0 \\
\hline
\end{tabular}




\begin{tabular}{|c|c|c|c|c|}
\hline Disease & $\begin{array}{l}\frac{1915}{\text { Death Rate }} \\
\underline{10}\end{array}$ & $\begin{array}{l}\text { Percentage } \\
\text { of Deaths }\end{array}$ & $\frac{1931}{\text { Death Rate }}$ & $\begin{array}{l}\text { Percentage } \\
\text { of Deaths }\end{array}$ \\
\hline Pneumonia & 15.5 & 28.7 & 6.2 & 58.5 \\
\hline $\begin{array}{l}\text { Bacillary } \\
\text { Dysentery }\end{array}$ & 17.6 & 32.5 & 0.6 & 5.7 \\
\hline $\begin{array}{l}\text { Typhoid- } \\
\text { Paratyphoid }\end{array}$ & 7.2 & 13.3 & 0 & 0 \\
\hline Other Diseases & 13.8 & 25.5 & 3.7 & 34.9 \\
\hline Accidents & n.a. & n.a. & 0.1 & 0.9 \\
\hline Total & 54.1 & 100.0 & 10.6 & 100.0 \\
\hline
\end{tabular}

Sources: Corner House: A.J. Orenstein, "A Review of the Hygiene Organisation of the Witwatersrand Gold Mines", in Proceedings of the Third Empire Mining and Metallurgical Congress (London, 1930), 134-148. Union Minière: R. Mouchet, "Documents anatamo-pathologiques sur la nosologie de la maind'oeuvre indigène a Elisabethville de 1915 a 1921", Bulletin I.R.C.B. 14, 2 (1943), 422-452; R. Van Nitsen, L'Hygiène des travailleurs noirs dans les camps industriels du Haut-Katanga (Bruxelles, 1933).

11 In Katanga as well as the Witwatersrand, pneumonia was the single most important cause of death both in the early years and around 1930. Both sites experienced a substantial decline of at least $50 \%$ in the death rate from pneumonia, but even at the latter dates, these rates were high by Panamanian standards. There the pneumonia death rate fell from nearly 19 per thousand in 1906 to 11 in 1907 to less the 3 per thousand after 1908 . The newly stabilized work force of the Union Minière was still experiencing a rate twice that high in 1931.

Why did mortality rates from pneumonia remain so high in the African mines? They did so in part because of the nature of the disease. Pneumonia does not come from a single bacillus but from no less than eighty strains, each requiring separate immunization. Incubation time is short, and those exposed to the bacillus either resist it in short order or come down with a serious case ${ }^{15}$. Another factor appears to have been crowding: as late as 1930, Orenstein reported that the optimal barracks size was ten to a room but that some still housed as many as forty ${ }^{16}$. Van Nitsen suggested in 1933 that no more than three single men should be housed in an individual dwelling ${ }^{17}$. Given the significance of the contribution of pneumonia to total mortality, the Union Minière's higher housing standards would appear to account for the fall in total mortality in the 1930s, when the Katanga mines began to approach Panamanian levels. Witwatersrand pneumonia death rates did not fall until the introduction of sulphonamids in the late $1930 \mathrm{~s}^{18}$. In sum, pneumonia mortality could be reduced through more than one policy. This was accomplished in Panama and, after 1931, in Katanga, by eliminating crowding, while in Johannesburg similar results had to await the introduction of broad-spectrum antibiotics. Another set of diseases where different companies practised different policies were the closely related conditions of typhoid and paratyphoid fevers. These conditions have similar symptoms and are transmitted through microscopic fecal particles in water and food $^{19}$. As with pneumonia, there is little delay between exposure and illness. Initially, mortality rates were considerably lower in South Africa than in Katanga. At the Corner House mines, mortality rates went from 2.8 per thousand per year in 1911 to 1.5 per thousand in 1928. The Union Minière rate began much higher, at 7.2 per thousand per year in 1915, but fell to 0 in 1930. Orenstein's staff seemed to consider a small amount of 
typhoid unavoidable. During the twenties, when inoculation provoked negative reactions in a number of workers, they experimented with an oral vaccine, and then abandoned efforts altogether ${ }^{20}$. The Union Minière, by contrast, inoculated all workers before they came to the mining camps and then gave them annual booster shots ${ }^{21}$.

One final domain for direct comparison is in death from industrial accidents. There the mortality rates at the Corner House mines vastly exceeded those at the Union Minière. In the former, mortality from accidents fell from 5.3. per thousand in 1911 to 3.3 in 1928. Three years later the Katanga rate was 0.1 per thousand. The most important factor accounting for this disparity is difference in working conditions. Most of the Katanga mines were open-cast, so that miners worked in the open air in daylight, while the South African gold mines were underground and subject to rockfalls, explosions of volatile gases, and injuries incurred in the darkness.

The incidence of three other diseases can not be compared directly from cause-specific mortality figures but nonetheless reveal differences between the disease pools of the two work forces. The first of these is tuberculosis which is often seen as a disease of the poor. Corner House statistics show a substantial decline in TB incidence, dropping from 3.7 per thousand in 1911 to 0.7 in $1928^{22}$. Comparable statistics for the early years at the Union Minière are not available, because Mouchet did not report them as a separate category in his summary of major causes of death for individual years. He does, however, include them in his analysis of 421 autopsies which he performed at Elisabethville between 1915 and 1921, and they amounted to roughly one-sixth of the pneumonia mortality, the equivalent of 2.5 per thousand in $1915^{23}$. By 1931, the death rate from tuberculosis had fallen to 0.4 per thousand ${ }^{24}$.

Interpretation of these figures is subject to considerable difference of opinion. Distinguished scholars such René Dubos and Randy Packard consider tuberculosis to be a consequence of the personal impoverishment brought by capitalism ${ }^{25}$. Indeed, wellhoused, well-nourished people may harbor the tuberculin bacillus in their systems without developing an active case. The link between work conditions and tuberculosis, however, is not necessarily direct. Even in undernourished people, tuberculosis takes a long time to incubate. I would therefore argue that people died from tuberculosis more as a result of the state of their metabolisms before they began work on the mines rather than from conditions on the job. Comparing incidence rates, this would lead to the conclusion that Africans came to the Corner House gold mines in worse nutritional condition than those who came to the Union Minière copper mines.

This hypothesis is strengthened by the incidence of scurvy, a Vitamin C deficiency disorder, in the Corner House causes of death. In 1911, scurvy caused fully two percent of the total deaths - a rate of 0.7 per thousand per year - which fell to 0.1 per thousand a year in 1928. Although Mouchet characterizes African workers from the villages as undernourished (and malarial), scurvy does not appear as a cause of death in either the early years or the 1930s. Thus, one might argue that Africans from South Africa and the High Commission territories were, in the early twentieth century, more likely to suffer from diseases of malnutrition than Africans from the Belgian Congo - a regularity which may be well linked to the expropriation of land by South African settlers.

Bacillary dysentery, by contrast, was a far more serious killer in tropical Katanga than in the sub-tropical Transvaal. In 1915, it produced an annual death rate of 17.6 per thousand, higher than pneumonia and accounting for nearly a third of all deaths. By 1931, its death rate had fallen to 0.6 per thousand. Corner House records do not provide a 
separate listing for bacillary dysentery, although Crown Mines reported a 1912 death rate of 0.9 per thousand. It would appear that bacillary dysentery was a far greater threat to Union Minière workers than to those at the Corner House group. This comparison, however, should not be taken as definitive, because it was often classed with typhoid and paratyphoid fevers as an enteric fever. Nonetheless, a higher incidence of dysentery would not be surprising in a tropical climate. Even there, however, its incidence is not inevitable; people can be protected from its rapid onset through a combination of clean water, washing hands, food, and eating utensils. Conditions would be especially bad in areas of dense population.

In summary, both the Corner House Group mines and those of the Union Minière presented dangers to the Africans who worked in them. Both companies made considerable advances in the care of their workers between the early 1910s and the 1930s. Despite top of the line medical expertise, both groups knew that they were doing less than an optimal job in protecting the health of their African workers. For the first twenty years of their existence, mortality rates in the Union Minière camps were far higher than those in the Corner House Camps, a condition not to be advertised. Even in the latter, however, death rates in 1928 were still higher than those prevailing twenty years earlier in the Panama Canal Zone. The failure was not so much one of medical technology as the unwillingness to spend sums necessary to clean up the mines as microenvironments. Mining managers were willing to spend money to improve the productivity of their respective work forces, but reducing African mortality was not their highest priority. Even the Panama black mortality rates were four times as high as those experienced by whites working on the Canal ${ }^{26}$.

These choices were a novelty in the history of both medicine and industry. By 1905, the consequences of the germ theory of disease were beginning to affect the practise of medicine in that the expenditure of money could produce more effect health care ${ }^{27}$. Managers, who had long realized that the output of their work forces depended at least in part on their health, were now confronted with deciding exactly how much to spend. In colonial Africa, as in the Panama Canal Zone, managers made two decisions: to spend relatively large sums on their European staffs and smaller sums on Africans. The gap between European and African care frequently depended on the processes by which companies allocated their resources. In order to understand improvements in health care, then, we need to learn more about these budgetary procedures.

\section{NOTES}

1. Richardson, Peter, Chinese Mine Labour in the Transvaal (London and Basingstoke, 1982). Jeeves Alan, Migrant Labour in South Africa'sMining Economy: the Struggle for the Gold Mines' Labour Supply, 1890-1920 (Kingston and Montréal, 1985).

2. Fetter Bruce, The Creation of Elisabethville, 1910-1940 (Stanford CA, 1976).

3. McCullough David, The Path between the Seas: the Creation of the Panama Canal, 1870-1914, (New York, 1977). 
4. Gorgas William C., "Recommendation as to Sanitation concerning Employéees of the Mines on the Rand Made to the Transvaal Chamber of Mines", Journal of the American Medical Society 62 (1914), 1855-65.

5. Cartwright A.P., Doctors of the Mines: A Commemorative Volume Published in 1971 to Mark the $50^{\text {th }}$ Anniversary of the Founding of the Mine Medical officers' Association of South Africa with a History of the Work of Mine Medical Officers (Cape Town, 1971), 28-37.

6. Comité Régional du Katanga, 3 Annexe 10, 19 avril 1921.

7. A.J. Orenstein to Elinor Bonner, $19^{\text {th }}$ November 1970 in Thomas Jefferson University Archives (Philadelphia), Alumni Office.

8. Fetter, Bruce, The Creation of Elisabethville, 83-94, 109-121.

9. Fetter, Bruce, "the Mines of Southern and Central Africa: An Ecological Framework", Paper presented at the Annual Conference of the British Society for Population Studies, Southampton, 1991.

10. Van Nitsen, R., L'Hygiène des travailleurs noirs dans les Camps industriels du Haut-Katanga (Bruxelles, 1933). Mottoulle, L., "Contribution à l'étude du déterminisme fonctionnel de l'industrie dans l'éducation de l'indigène congolais", Mémoires de l'Institut Royal Colonial Belge, III (1934).

11. Mouchet, R., "documents anatomo-pathologiques sur la nosologie de la main-d'oeuvre indigène à Elisabethville de 1915 à 1921", Bulletin de l'Institut Royal colonial Belge, (14 (1943), 422-452. The most complete account of Union Minière mortality and morbidity is to be found in Dibwe dia Mwembu, "Industrialisation et santé. La transformation de la morbidité à l'Union Minière du Haut-Katanga, 1910-1970, "Ph. D. thesis. Université Laval, 1990.

12. Orenstein Alexander, "A Review of the Hygiene Organisation of the Witwatersand Gold Mines", in Proceedings of the Third Empire Mining and Metallurgical Congress, (London, 1930), 134-148. 13. Abraham John C., Report on Nyasaland Natives in the Union of South Africa and in Southern Rhodesia, (Zomba, 1937).

14. Gorgas, "Recommendation".

15. Burnet, Macfarlane and White ,David O., Natural History of Infectious Disease, $4^{\text {th }}$ edition (Cambridge, 1972), 74-76.

16. Orenstein, "Review".

17. Van Nitsen, L'hygiène, 33.

18. Cartwright, Doctors of the Mines, 109-124.

19. Burnet and White, Natural History, 125-126.

20. Cartwright, Doctorsof the Mines, 141.

21. Van Nitsen, L'hygiène, 207-213.

22. Orenstein, "Review".

23. Mouchet, "Documents".

24. Van Nitsen, L'hygiène, 185-188.

25. Dubos, R. and J., The White Plaque (Boston, 1953). Packard, Randall M., White Plaque, Black Labor: Tuberculosis and the Political Economy of Health and Disease in South Africa (Berkeley and Los Angeles, 1989).

26. McCullough, Pathbetween the Seas, 582.

27. Preston, Samuel H. and Haines, Michael R., Fatal Years: Child Mortality in Late NineteenthCentury America (Princeton, 1991). 


\section{ABSTRACTS}

En comparant les changements intervenus dans les causes de décès au sein de deux des plus grandes compagnies minières d'Afrique, il est possible de mieux cerner les caractéristiques des forces productives et les différences dans les politiques médicales de ces compagnies. Tant le "Corner House Group" de Witwatersrand que l'Union Minière du Katanga ont été réticents à rendre public les niveaux de mortalité parmi leurs travailleurs africains et les causes de décès de ceux-ci. Cet article tentera d'analyser les données statistiques que l'on peut trouver dans quelques publications peu répandues. Ces données permettront de mieux comprendre les conséquences sanitaires des premières étapes du processus d'industrialisation de l'Afrique.

\section{AUTHOR}

\section{BRUCE FETTER}

University of wisconsin - College of Letters and Science - Milwaukee - USA 